\title{
PROSES PERMESINAN CNC DALAM PEMBELAJARAN SIMULASI CNC
}

\author{
Eko Prianto ${ }^{1}$, Herlambang Sigit Pramono ${ }^{2}$ \\ ${ }^{1,2}$ Jurusan Pendidikan Teknik Elektro Fakultas Teknik Universitas Negeri Yogyakarta \\ email : eko_prianto@uny.ac.id, herlambang@uny.ac.id
}

\begin{abstract}
This article aims to identify the materials for the appropriate simulations in the CNC learning process along with the introduction of the various stages required in the CNC machining process. The selected simulation program has the ability to provide an overview in running the CNC machine and its control especially for CNC 3 axis systems. This article describes the requirements of an appropriate CNC simulation learning course. These requirements are related to the competence that must be achieved by the students after following the CNC simulation course.
\end{abstract}

Keywords : Simulation, CNC, Learning

ABSTRAK

Artikel ini bertujuan untuk mengidentifikasi materi untuk simulasi yang sesuai dalam proses pembelajaran $\mathrm{CNC}$ beserta pengenalan berbagai tahapan yang diperlukan dalam proses permesinan $\mathrm{CNC}$. Program simulasi yang dipilih memiliki kemampuan untuk memberikan gambaran dalam menjalankan mesin CNC beserta pengendaliannya terutama untuk $\mathrm{CNC}$ sistem 3 axis. Artikel ini menjelaskan tentang syarat-syarat yang dibutuhkan sebuah dalam pembelajaran simulasi CNC yang sesuai. Syarat tersebut terkait dengan kompetensi yang harus dicapai oleh mahasiswa setelah mengikuti mata kuliah simulasi CNC.

Kata Kunci : Simulasi, CNC, Pembelajaran

\section{PENDAHULUAN}

Computer Numerical Control (CNC) merupakan salah satu komponen inti dalam suatu proses manufaktur presisi yang harus dikuasai oleh mahasiswa terutama mahasiswa teknik mekatronika. Proses permesinan CNC diawali dengan mendesain obyek menggunakan software berbasis Computer Aided Design (CAD) kemudian diteruskan ke dalam proses manufacturing menggunakan software berbasis Computer Aided Manufacturing (CAM)) yaitu sebuah teknologi aplikasi yang menggunakan perangkat lunak komputer dan mesin untuk memfasilitasi dan mengotomatisasi proses manufaktur. Computer Aided Manufacturing (CAM)) sering digunakan bersama dengan Computer-Aided Design (CAD). Perangkat lunak berupa integrasi bersama antara CAD dan CAM disebut sebagai CAD/CAM software sebagai contoh MaterCAM. Selain persyaratan bahan, sistem Computer Aided Manufacturing
(CAM) modern meliputi kontrol real-time dan robotika. Simulasi proses cutting/pembentukan benda kerja dalam software CAD/CAM dapat disimulasikan.

Mesin CNC menjadi bagian utama dari proses pengenalan instruksi mesin dan program pelatihan di sebagian besar sekolah menengah kejuruan dan unit pelatihan kejuruan. Bagi siswa, sangat penting untuk belajar memprogram CNC karena mereka dapat menggunakan teknik pemrograman $\mathrm{CNC}$ untuk menulis program dalam membuat benda kerja, yang merupakan basis dari teknologi perancangan dan desain komputer (CAD / CAM). Namun demikian, karena tingginya biaya pengadaan peralatan atau tidak tersedianya peralatan yang memadai, dan sering terjadi kerusakan peralatan akibat penggunaan yang tidak tepat. Hal ini berakibat peserta didik kurang memiliki pengalaman mengoperasikan mesin CNC secara langsung, sehingga hasil belajar tidak tercapai secara optimal. 
Untuk membantu mengatasi masalah tersebut maka Program Simulasi biasanya digunakan dalam proses pembelajaran. Alat bantu berupa perangkat lunak dalam suatu pembelajaran berbantuan komputer dapat meningkatkan keefektifan pembelajaran siswa. Program Simulasi memungkinkan peserta didik untuk berpartisipasi aktif dalam kegiatan belajar. Simulasi dianggap sebagai metode pembelajaran yang paling efektif dan efisien dalam belajar dan mempelajari sistem yang kompleks dan dinamis sehingga dapat menghemat waktu dan menghasilkan hasil belajar yang lebih baik daripada metode lainnya. Selanjutnya, pembelajaran dalam hal teknologi pemrosesan numerik, hasil implementasi berupa kode CNC, debugging, penambahan penulisan dalam suatu kode program, dan simulasi gerakan pemotongan alat potong tidak hanya dapat membantu pengajar dalam mengajar secara efektif tetapi juga meningkatkan kemampuan teknis dan motivasi belajar peserta didik dengan memperpendek waktu pembelajaran mereka.

Berdasarkan ketersediaan kajian di internet dan pengembangan teknologi yang relevan, penelitian tentang sistem simulasi berbasis program $\mathrm{CNC}$ telah mencapai beberapa kemajuan. Misalnya, penelitian yang dilakukan oleh Huang mengembangkan laboratorium manufaktur terpadu berbasis Internet sebagai pelengkap instruksi dalam berbagai modul manufaktur. Kemudian Cheng menggunakan CORBA (Common Object Request Broker Architecture) untuk membangun sistem simulasi instruksional program CNC jarak jauh. Selanjutnya, Hutchinson dan Kuester, serta Ong dan Mannan menerapkan Virtual Reality (VR) tools untuk simulasi 2D dan 3D; peneliti tersebut membangun lingkungan fisik 'VizClass', menggunakan whiteboard dan materi pengajaran digital (seperti simulasi CNC) untuk menciptakan visualisasi di kelas. Peneliti yang terakhir ini menerapkan VRML dan Java untuk membangun lingkungan CNC virtual yang menyediakan fungsi viewing, insert the word, dan fill the blank. (Jeremic, 2014)
Pembelajaran mesin CNC merupakan masalah yang mendesak di industri mesin, namun implementasinya dibatasi oleh dana pengadaannya. Untuk meningkatkan pembelajaran praktik, di Jerman menetapkan pelatihan dan metode pembelajaran $\mathrm{CNC}$ yang dilakukan oleh DIN 66025. Upaya mereka untuk meningkatkan efisiensi pendidikan dengan pengembangan peralatan mesin $\mathrm{CNC}$ untuk pendidikan mencakup program simulasinya. Secara teori, menggunakan mesin CNC skala industri dapat memaksimalkan efisiensi pendidikan, namun dalam pelaksanaannya, ketakutan akan kesalahan dalam pengoperasian dan pengembangan program, mesin $\mathrm{CNC}$ dapat mengalami kerusakan dan akan menambah pembiayaan yang tinggi. Tetapi mesin $\mathrm{CNC}$ dapat digunakan secara efektif untuk tujuan pendidikan yaitu dengan menggunakan mesin $\mathrm{CNC}$ yang memiliki ukuran struktur mesin dan peralatan kontrol yang lebih kecil sehingga mudah dipelajari dan memungkinkan dilakukannya koneksi dan perakitan. Selain itu, peralatan khusus untuk setting tidak diperlukan karena mesin CNC memiliki biaya yang rendah, berat dan ukurannya kecil, dan memungkinkan pergerakan yang variatif. Dengan demikian, masing-masing jenis mesin $\mathrm{CNC}$ memiliki kekurangan dan kelebihan, perlu agar berbagai program disarankan untuk dilaksanakan termasuk program investigasi dan pelaksanaan pembelajaran dalam menghasilkan mesin $\mathrm{CNC}$ berikut cara memasukan data teknis, yaitu metode pengaturan peralatan, ukuran kecepatan pemotongan secara interpolasi dan pengaturan gerak makan. (Jeremic, 2014)

Hasil penelitian mengenai proses pembelajaran berbantuan komputer ini didukung penelitian oleh Taufik (2010:34) di dalam Jurnal Teknologi dan Kejuruan menyimpulkan bahwa prestasi belajar siswa mengalami peningkatan yang signifikan dengan pembelajaran berbantuan komputer menggunakan Software Mastercam memberi dampak pada hasil belajar siswa yang lebih baik. 
Dalam proses mendesain sampai membentuk benda kerja menggunakan mesin $\mathrm{CNC}$, mesin $\mathrm{CNC}$ dioperasikan dengan menggunakan kontrol komputer dan gerakan alat pemotong diatur dalam program NC. Kualitas bagian mesin tergantung pada pemilihan parameter pemotongan dan cara pemotongan. Untuk memfasilitasi parameter tersebut, program NC yang sesuai harus dipersiapkan. Program ini berisi daftar kode yang bisa dimengerti oleh pengontrol mesin CNC. Pemrograman NC adalah pekerjaan pada mesin yang monoton dan membutuhkan waktu, tetapi sebenarnya merupakan pekerjaan yang tidak dapat dihindari. Program NC yang salah dapat menyebabkan pemborosan bahan baku, memperpendek umur alat, membuang waktu produksi dan lain-lain. (Bagus Arthaya, 2010)

Kualitas hasil dalam pembuatan benda kerja menggunakan mesin $\mathrm{CNC}$ tergantung pada posisi relatif antara posisi benda kerja, alat pemotong, parameter proses pemesinan. Hal ini dapat dicapai jika perlengkapan mesin CNC memiliki kekuatan yang cukup untuk menahan gaya pemotongan, kekakuan terhadap deformasi bahan dan kemampuan CNC Controller-nya. CNC Controller merupakan jantung mesin CNC yang mengendalikan sebagian besar fungsi mesin CNC. Komponen CNC Controller bertanggung jawab untuk memposisikan sinyal yang dibuat menggunakan komputer dan bekerja sama dengan perangkat lunak NC dalam pengendalian motor yang sesuai. Keseluruhan proses tersebut secara bersama membuat sistem kontrol total. Ada tiga komponen dasar pengendali CNC. (1) Unit catu daya (2) Unit sistem proteksi rangkaian (3) Unit penggerak motor. (Rajendra Rajput, 2016). Masing-masing komponen dalam proses pengendalian sebuah mesin CNC tersebut merupakan syarat mutlak yang harus dimiliki mahasiswa sebelum mempelajari mesin CNC. Syarat tersebut dapat terpenuhi apabila mahasiswa telah mengambil mata kuliah yang terkait tiga komponen diatas.

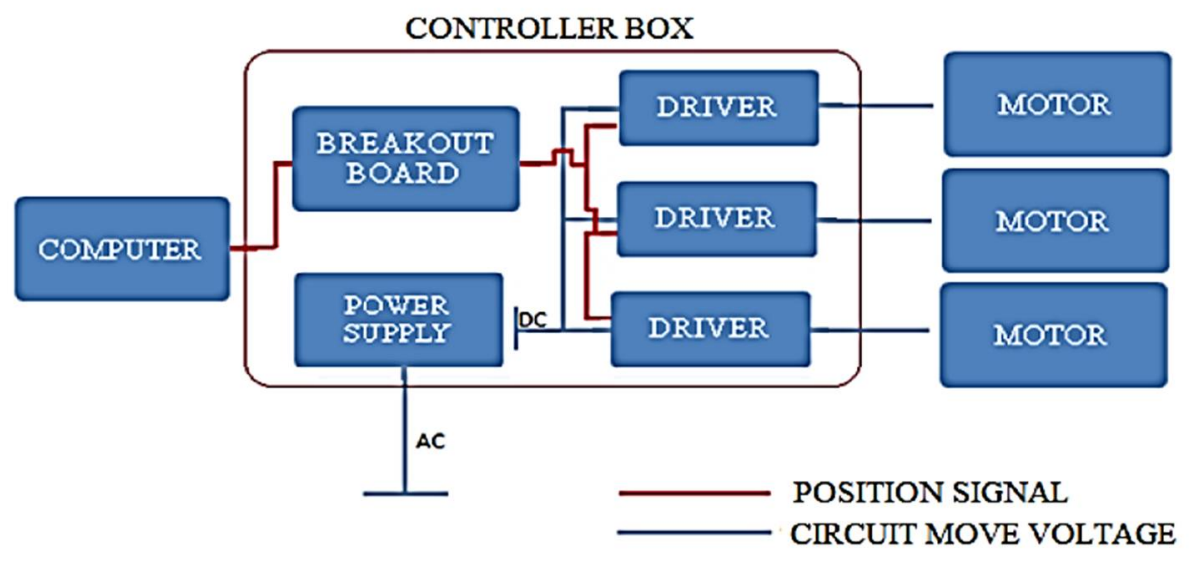

Gambar 1. Blok Diagram Controller Mesin CNC

(Rajendra Rajput, 2016)

Proses pembuatan benda kerja dari desain sampai benda jadi seperti diatas menjadi suatu kebutuhan yang harus dikuasai mahasiswa. Dengan berbagai kendala yang ada dalam pelaksanaan pembelajaran di kampus, pembelajaran berbasis simulasi sangat dibutuhkan untuk mencapai tujuan yaitu tercapainya standar kompetensi mahasiswa dalam pengenalan mesin $\mathrm{CNC}$ beserta prosesnya.

\section{ANALISIS PEMECAHAN MASALAH}

Dalam proses pembelajaran simulasi CNC diperlukan software yang sesuai dengan kompetensi yang diharapkan setelah mengikuti pembelajaran simulasi CNC. Dilihat dari proses 


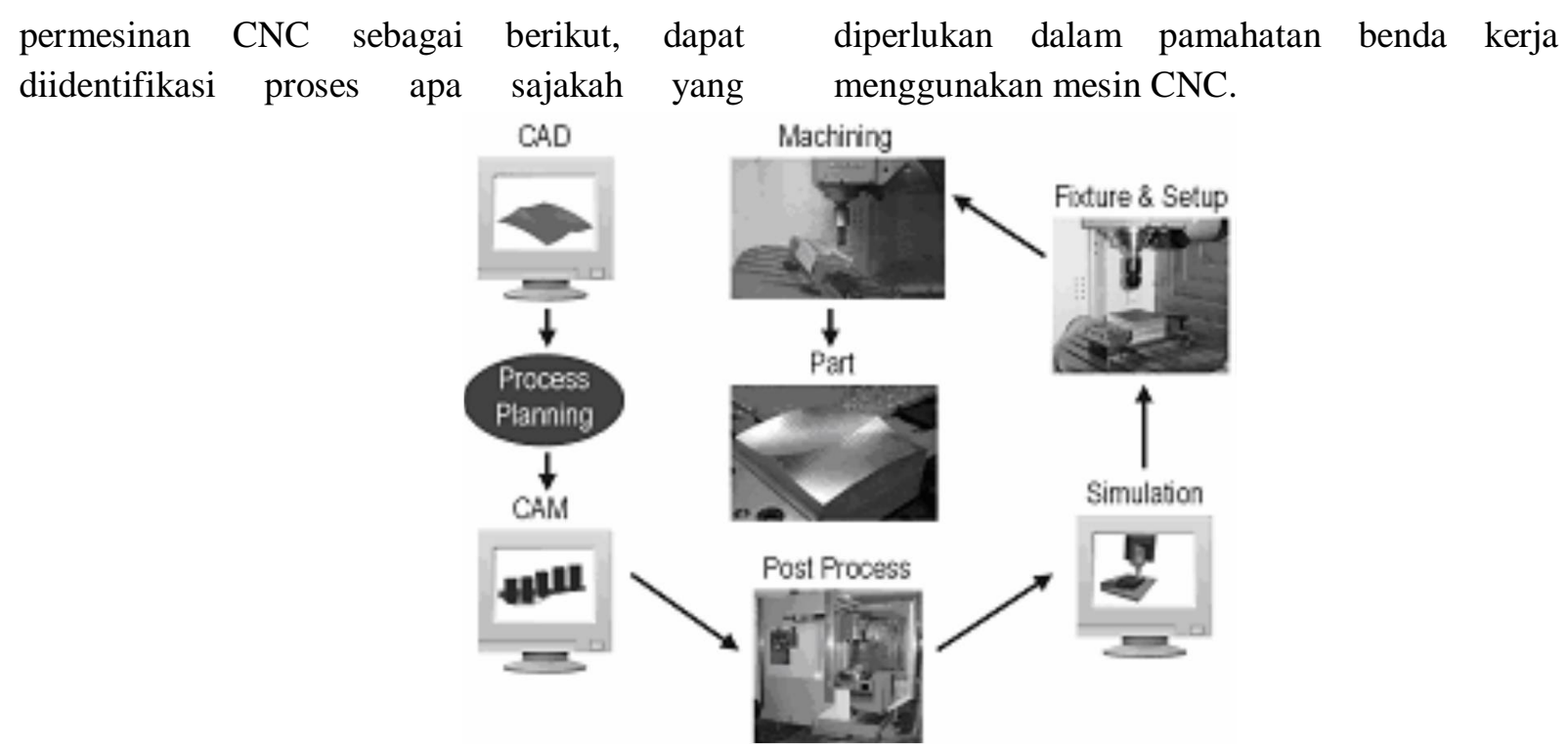

Gambar 2. Proses Permesinan CNC

(Gray dkk)

Berdasarkan gambar tersebut diatas, dalam proses permesinan $\mathrm{CNC}$, langkahlangkah yang harus dilakukan mahasiswa yaitu; merencanakan dan menggambar benda kerja di software CAD; memproses gambar menjadi kode-kode numeric menggunakan software CAM; menguji kode numeric tersebut di dalam software simulasi; apabila kode tidak bermasalah, dilanjutkan dengan memasukkan parameter benda kerja pada mesin $\mathrm{CNC}$, memasukkan kode-kode numeric yang telah diuji ke dalam mesin CNC dan menjalankan mesin CNC untuk memproses sehingga menghasilkan benda kerja sesuai rancangan.

Menurut definisi dari Departemen Pendidikan Nasional (2005) mendeskripsikan bahwa metode pembelajaran simulasi adalah bentuk metode praktek yang sifatnya untuk mengembangkan keterampilan peserta didik (ranah kognitif maupun psikomotorik) dengan memindahkan suatu situasi yang nyata ke dalam kegiatan atau ruang belajar karena adanya kesulitan dan keterbatasan untuk melakukan praktik di dalam situasi yang sebenarnya. Tujuan metode pembelajaran simulasi adalah ; peserta didik memiliki gambaran lebih jelas tentang hal yang berhubungan dengan proses mengatur sesuatu, membuat sesuatu, terjadinya sesuatu, mengerjakan atau menggunakan sesuatu dan komponen-komponen yang membentuk sesuatu; untuk menghindari terjadinya verbalisme pada peserta didik; proses pembelajaran menjadi lebih menarik; menerapkan student center learning; merangsang peserta didik lebih aktif mengamati, menyesuaikan, antara teori dan kenyataan dan mencoba mempraktikkan apa yang ada dalam teori menjadi sesuatu yang lebih nyata. Salah satu hal penting yang menjadi karakteristik dalam pembelajaran simulasi adalah penerapan learning by doing yaitu dengan mengadirkan langsung kondisi menggunakan "realita buatan" dan diharapkan meningkatkan pemahaman materi tersebut untuk diaplikasikan dalam praktiknya.

\section{Syarat Pelaksanaan Pembelajaran Simulasi CNC}

Pertama, menurut Depdiknas (2005), metode pembelajaran simulasi membutuhkan ketersediaan bahan dan alat yang memadai dalam pelaksanaannya. Dalam pelaksanaan pembelajaran simulasi $\mathrm{CNC}$ alat dan bahan yang dibutuhkan adalah komputer yang dilengkapi perangkat lunak simulasi CNC. Kedua, menurut Djamarah (2006), kesiapan pengajar dalam melaksanakan simulasi. Hal ini 
merupakan hal yang sangat penting dimana pengajar harus benar-benar memahami, berperan sebagai sutradara sehingga pembelajaran tidak keluar dari konteks, serta membuat perencanaan yang jelas. Ketiga, kesiapan peserta didik dalam melaksanakan simulasi, peserta didik harus memepersiapkan diri sebaik-baiknya dengan memahami apa yang harus dilakukan dalam simulasi. Keempat, waktu yang disediakan cukup untuk melaksanakan pembelajaran simulasi.

Keempat syarat diatas, telah dapat dipenuhi dalam melaksanakan pembelajaran simulasi CNC di Jurusan Pendidikan Teknik Elektro FT UNY. Hal ini ditunjukkan dengan bahan dan alat yang tersedia yaitu komputer yang dilengkapi dengan perangkat lunak simulasi CNC, dimana software yang digunakan adalah swansoft CNC. Dalam mengajar dosen telah dilengkapi dengan rencana pembelajaran dalam satu semester (RPS) dimana terdapat tujuan dan indikator yang jelas dalam setiap pertemuan beserta modul praktikum. Pada 4 pertemuan awal, mahasiswa diberikan materi terkait dengan teori dasar $\mathrm{CNC}$, komponen mesin $\mathrm{CNC}$ dan kode numerik yang digunakan dalam mesin CNC. Pertemuan ke 5 dan selanjutnya dilaksanakan aplikasi menggunakan software simulasi untuk mesin CNC mill dan CNC bubut. Dari 4 pertemuan awal diharapkan mahasiswa memiliki kesiapan sebagai bahan untuk melaksanakan praktikum, pelaksanaan pemberian dasar mesin CNC ini menggunakan metode ceramah. Waktu yang disediakan dalam pembelajaran simulasi $\mathrm{CNC}$ ini adalah 16 pertemuan dimana setiap pertemuan dilaksanakan selama 200 menit sehingga waktu yang disediakan cukup untuk melaksanakan pembelajaran baik teori maupun praktik.

Mesin CNC dibagi menjadi beberapa jenis, dintaranya ; Mesin CNC Tarus yaitu mesin $\mathrm{CNC}$ milling dengan desain 1 lengan; CNC Router yaitu mesin CNC dengan desain tiang penyangga sumbu X 2 kolom; Mesin CNC Milling Vertical yaitu CNC skala industri yang biasanya digunakan dalam industri manufaktur; PC based CNC yaitu mesin CNC yang memiliki sistem pemrograman $\mathrm{CNC}$ dengan menggunakan software yang terinstal dalam Personal Computer sebagai pengontrolnya. Menurut Zhu, ditinjau berdasarkan teknik pengontrolannya, terdapat beberapa jenis sistim kendali mesin perkakas $\mathrm{CNC}$, diantaranya sistim kontrol loop terbuka (open loop control system) dan sistim kontrol loop tertutup (closed loop control system). Sistim kontrol terbuka menggunakan penggerak berupa motor stepper yang merupakan sistem kendali murah dan mudah, dibanding sistem kontrol tertutup. Pada sistim kontrol terbuka tidak digunakan alat ukur posisi yang mampu memberikan umpan balik (feedback) seperti pada sistim kontrol tertutup. Karena merupakan loop kontrol yang terbuka, sehigga sistem ini mudah dipengaruhi oleh gangguan dari luar, dan ketelitian gerakan (kesalahan jarak /pengaturan posisi) juga terpengaruh.

Dalam proses pembelajaran simulasi $\mathrm{CNC}$, mesin $\mathrm{CNC}$ yang digunakan dalam software simulasi menggunakan CNC Sinumerik, GSK dan Fanuc, baik untuk proses milling maupun bubut/lathe.

\section{Pelaksanaan Pembelajaran Simulasi CNC}

Proses dalam melaksanakan pembelajaran simulasi CNC ini dimulai dari pembuatan desain benda kerja menggunakan software CAD, kemudian dilanjutkan mengubah desain menjadi kode-kode numerik (NC kode). Selanjutnya kode numerik yang dihasilkan diuji kebenarannya dalam suatu software simulasi $\mathrm{CNC}$.

Proses desain dan pengubahan desain menjadi kode numerik dilakukan dengan software CAD/CAM, salah satunya adalah MasterCam. Mastercam adalah perangkat lunak komputer berbasis CAD/CAM (Computer Aided Design/Computer Aided Manufacturing). Aplikasi ini digunakan untuk mendesain dan membuat program $\mathrm{CNC}$ untuk proses pemesinan (Mastercam, 2002:1). Perangkat lunak mastercam memiliki empat ikon yaitu, mastercam yang digunakan untuk menggambar 
(design), proses bubut (Lathe), proses frais (Mill), proses wire cutting. Perangkat lunak komputer berbasis CAD/CAM yang memiliki fasilitas komputer grafis dengan memungkinkan penggunanya untuk melakukan berbagai bentuk simulasi proses pemesinan sebelum diimplementasikan pada proses pemesinan yang sesungguhnya.

Kode ( $G$-code) dasar yang digunakan dalam Proses Pembelajaran :

\begin{tabular}{|c|c|}
\hline G90 & : Kode untuk mode absolute \\
\hline G90 & $\begin{array}{l}\text { : Kode untuk mode } \\
\text { Incremental }\end{array}$ \\
\hline G54 & $\begin{array}{l}\text { : Kode untuk offset titik } \\
\text { kerja mesin }\end{array}$ \\
\hline G00 & $\begin{array}{l}\text { : Kode untuk menjalankan } \\
\text { pisau pahat dengan gerak } \\
\text { cepat tanpa melakukan } \\
\text { pemahatan. }\end{array}$ \\
\hline G01 & $\begin{array}{l}\text { : Kode untuk menjalankan } \\
\text { pisau pahat dengan interpolasi } \\
\text { linier dan melakukan } \\
\text { pemahatan. }\end{array}$ \\
\hline $\mathrm{X} 0, \mathrm{Y} 0 \mathrm{Z} 0$ & $\begin{array}{l}\text { : Kode untuk inisialisasi titik } \\
\text { kerja awal mesin }\end{array}$ \\
\hline X Y Z & $\begin{array}{l}\text { : Kode untuk pergerakan } \\
\text { arah X, Y dan Z }\end{array}$ \\
\hline $\mathrm{F}$ & $\begin{array}{l}\text { : Kode untuk menetukan } \\
\text { Feed rate atau kecepatan } \\
\text { gerak mesin }\end{array}$ \\
\hline M02 & $\begin{array}{l}\text { : Kode untuk menyatakan } \\
\text { proses berakhir }\end{array}$ \\
\hline
\end{tabular}

Kode yang dihasilkan dari proses CAD/CAM kemudian dimasukkan ke dalam sistem control yang terdapat dalam software simulasi CNC, dalam hal ini software yang

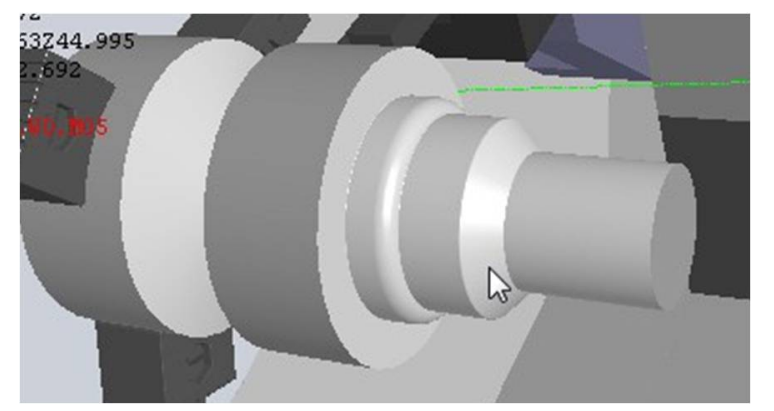

Gambar 3. Hasil Pembuatan Benda Kerja Menggunakan CNC Fanuc OiT Lathe digunakan adalah Swansoft CNC. Setelah kode dimasukkan kemudian dilakukan penyesuaian beberapa parameter agar hasil yang diperoleh dalam proses simulasi sesuai dengan desain rancangan. Berdasarkan proses yang harus dilalui dalam mempelajari mesin $\mathrm{CNC}$ melalui software simulasi, maka dapat diidentifikasi materi yang sesuai dengan tujuan yang ingin dicapai yaitu :

1. Dasar Proses Permesinan CNC (Konstruksi mesin $\mathrm{CNC}$ )

2. Sistem koordinat dan Geometri Cutting Tool

3. Kode-kode Numerical Control pada mesin $\mathrm{CNC}$

4. Pengenalan Unit Control pada software simulasi CNC baik mill maupun lathe yang terdiri dari mesin CNC Sinumerik, Fanuc dan GSK.

5. Setting titik nol mesin dan bahan

6. Proses memasukkan kode NC ke dalam simulator

7. Proses Face, Pocket dan Contour pada CNC Mill

8. Proses Rough, Drill dan Finish pada CNC Mill

9. Proses bubut step dan radius pada $\mathrm{CNC}$ Lathe/Turning

10. Proses Face, Rough, Groove, Thread dan Drill pada CNC Lathe/Turning baik untuk bubut bagian luar atau dalam

Berikut contoh hasil pembelajaran simulasi CNC untuk CNC Mill maupun CNC Lathe :

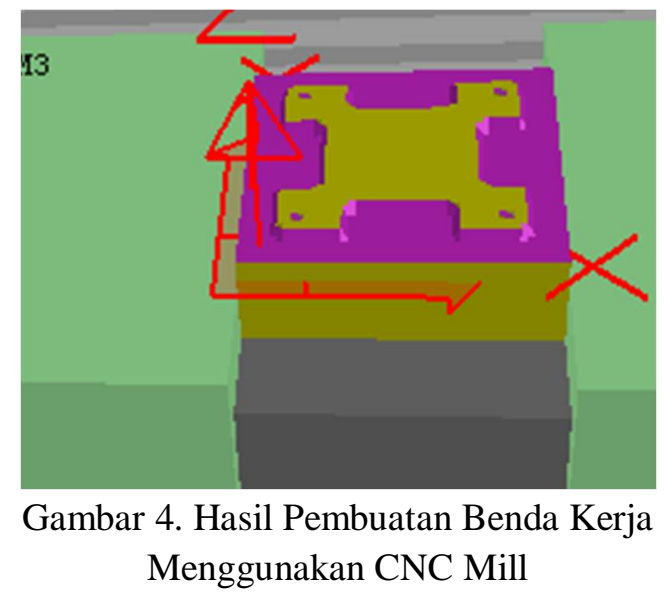




\section{SIMPULAN}

Berdasarkan penelitian sebelumnya, simulasi dianggap sebagai metode pembelajaran yang paling efektif dan efisien dalam belajar dan mempelajari sistem yang kompleks dan dinamis contohnya dalam mempelajari proses permesinan CNC. Pendekatan pembelajaran dengan menggunakan software simulasi untuk mempelajari mesin $\mathrm{CNC}$ sangat tepat digunakan untuk lembaga pendidikan yang memiliki anggaran pengadaan yang minim.

Proses dimulai dari mendesain sampai menghasilkan benda kerja dapat dilakukan menggunakan software simulasi CNC yang tepat, baik software yang berdiri sendiri untuk keseluruhan proses maupun kombinasi berbagai kombinasi software sehingga proses permesinan CNC dapat dilakukan menggunakan perangkat komputer.

Ketersediaan bahan dan alat yang memadai, kesiapan pengajar, kesiapan mahasiswa dan waktu yang disediakan sebagai syarat dari pelaksanaan pembelajaran simulasi CNC telah terpenuhi sehingga proses pembelajaran untuk mempelajari mesin $\mathrm{CNC}$ dapat dilakukan melalui pendekatan pembelajaran menggunakan software simulasi di Prodi Pendidikan Teknik Mekatronika FT UNY.

Proses pembelajaran simulasi $\mathrm{CNC}$ tersebut dimulai dari pembuatan desain benda kerja menggunakan software CAD, kemudian dilanjutkan mengubah desain menjadi kodekode numerik (NC kode). Kode numerik yang dihasilkan diuji kebenarannya dalam suatu software simulasi CNC.

\section{DAFTAR RUJUKAN}

Bagus Arthaya, dkk. 2010. The Design and Development of G-code Checker and Cutting Simulator for CNC Turning Operation. Journal of Mechanical
Engineering Research Vol. 2(3), pp. 58-70.

E Unver and M Mavromihales. 2001. Design and Development of an interactive $3 D$ CNC Computer Aided Learning Program. In: 17th International Conference on CAD/CAM, Robotics and Factories of Future, 10-12 July 2001, Durban, South Africa. url : http://eprints.hud.ac.uk/7794/

Gilbert Poon, Paul J. Gray, Sanjeev Bedi and Daniel Miller. Architecture for Direct Model-to-Part CNC Manufacturing. Systemics, Cybernetics And Informatics Volume 4 - Number 1 ISSN: $1690-4524$.

Jeremic, Marija et. al. 2014. Computer Numerical Control Simulation Tool for Teaching and Learning of Engineering Students. 8th International Quality Conference, Center for Quality, Faculty of Engineering, University of Kragujevac.

Rajendra Rajput and Dr. Ajay Kumar Sarathe. 2016. Comparative Study of CNC Controllers used in CNC Milling Machine. American Journal of Engineering Research (AJER), Volume-5, Issue-4, pp-54-62.

Rakib Hasan, Sakib Shahazad Ali, Dr. Tarapada Bhowmick. 2014. Simulation of a workpiece in CNC milling machine on the basis of $G$ and $M$ code based NC programming. International Conference on Mechanical, Industrial and Energy Engineering 2014, 25-26 December 2014, Khulna, Bangladesh.

Zhu, S., Ding, G., Qin, S., Lei, J., Zhung, L. and Yan, K., 2011. Integrated Geometric Error Modeling, Identification and Compensation of CNC Machine Tools. International Journal of Machine Tools \& Manufacture 52 (2012) 24-29 